\title{
Ideology and philosophy of the successful regional development in contemporary Russia: The Belgorod case
}

\author{
A.Nikulin, I.Trotsuk, S.Wegren
}

\begin{abstract}
Alexander Nikulin, PhD (Economics), Head of the Center for Agrarian Studies, Russian Presidential Academy of National Economy and Public Administration. Prosp. Vernadskogo, 82, Moscow, Russian Federation, 119571. E-mail: harmina@yandex.ru

Irina Trotsuk, DSc (Sociology), Senior Researcher, Center for Agrarian Studies, Russian Presidential Academy of National Economy and Public Administration; Associate Professor, Sociology Chair, RUDN University. Prosp. Vernadskogo, 82, Moscow, Russian Federation, 119571. E-mail: irina.trotsuk@yandex.ru
\end{abstract}

Stephen Wegren, Professor of Political Science, Southern Methodist University, Dallas, Texas, USA. E-mail: swegren@smu.edu

The article considers economic successes of the Belgorod region as significantly determined by the governor Yevgeny Savchenko' agrarian policies, which compensate for the region's small size and modest human capital. In 2017, the authors published an article describing economic policies and social programs of regional authorities; now the authors focus on the leadership by Yevgeny Savchenko, and his rather paradoxical personal and management views. First, according to Max Weber's typology of authority, Savchenko is a charismatic leader with strong personality traits and careful political behavior, who benefits from the traditional Slavophile populism and institutional design of the gubernatorial powers that has allowed governors to become more powerful compared to other regional actors during 2002-2012. Second, the Belgorod governor's project has quite traditional Russian roots in the spirit of A.V. Chayanov's novel "My brother Alexey's journey to the land of peasant utopia”, which allowed the Belgorod modernization project to successfully cope with unpredictable challenges from the Russian oligarchy and global economy, and to use competitive standards of consumer society as the grounds for conservative modernization and solidary society development. The Belgorod governor implements his own model of new economy consisting of the extensive development of solidarity and cooperation; ideals of healthy lifestyle; and freedom in choosing ways to work and to rest (regional authorities support corporate, family and individual strategies of life). Third, Savchenko has publicly articulated his personal political-economic theory reflecting a conglomerate of conservative, socialist and populist ideas, and combining anti-liberalism and statist philosophy as the basis for the revival of the Russian state, which the governor sees as an engine of social progress.

Keywords: Belgorod region; governor; leadership; regional authorities; regional development; ideological roots; philosophical foundations

DOI: 10.22394/2500-1809-2018-3-1-99-116 
The Belgorod region is one of the most economically successful regions of the Russian Federation. This rather small region is located in the central black-earth zone of Russia and borders on Ukraine. It occupies an area approximately equal to the Crimean peninsula (about 27 thousand square kilometers), and has population of 1.5 million people. The urban share of the population is 70 percent, while 30 percent are rural, and the capital city Belgorod has $35^{\circ}$ thousand inhabitants. The region has distinct economic and geographical advantages for it possesses the world's largest iron ore deposits and agricultural lands located in the centre of the vast Russian-Ukrainian black soils. Moreover, the region boasts weather and natural resources favorable for agricultural production, and has been very successful in fulfilling its objectives for the development of agriculture. Belgorod is well known for housing largest and successful agroholdings, and for ranking among the leaders in agricultural production, especially of pork and poultry.

Savchenko's agrarian policies have been called the "Belgorod Miracle," referring to the region's achievements as a major Russian agricultural producer (see, e.g.: Reiting, 2016) although Belgorod was not among agricultural leaders in the late Soviet or early post-Soviet periods, i.e. before Savchenko became governor (Ioffe, Nefedova, 2000: 299). The Belgorod region's high ranking in agricultural production is even more impressive for in 2014 it ranked 67th in territorial size, 22rd in the size of agricultural workforce, and 3 oth in the size of population. Belgorod has become one of the strongest agricultural producers in the country, ranking in the top five in terms of ruble value of agricultural production since 2008, and ranking 3rd in 2014 and 2015 and 4 th in 2016 . In 2016 , the region produced almost $6 \%$ of the nation's total meat output (Kulistikova, 2017). Moreover, during 20052010 the nominal ruble value of agricultural output in the Belgorod region tripled (for comparison: in the Krasnodar region the output doubled, the national agricultural sector grew by $87 \%$ (Rosstat, 2015: 641-642); for animal husbandry, the growth rate was nearly three times as high as in the Krasnodar region and the rest of the country (Fadeeva, 2013: 423)).

Savchenko's policies compensate for Belgorod's small size and modest human capital by the significant modernization (mechanization) of agricultural production, promotion of agroholdings that use technologically advanced methods of production, and regional projects for the development of agriculture. Thus, the region has the smallest amount of land that is unclaimed in the Central Federal district; in the last decade, the region has shown very strong growth in pork and poultry production, making the sector competitive with Western European and American companies; the region consistently ranks among national leaders in crop production and grain yields, and so on. 
Certainly, such an economic success was determined by the general revival of the Russian agricultural sector since 2004. For instance, the value of national agricultural production increased from 1.3 trillion Rubles in 2004 to 5.6 trillion Rubles in 2016 under the state financial support and wide-ranging state programs for agricultural development (Wegren, Nilssen, Elevastad, 2016). Since 2014, the agricultural sector has grown so fast that Russia regained the position of the world leading wheat exporter in $2015^{-2017}$. By the way, Savchenko was among the politicians who claimed that Russia has the potential to produce enough grain, meat, milk and other products not only to be self-sufficient but to feed half a billion people (see, e.g.: Dyatlovskaya, 2016; Evgeniy Savchenko: Rossiya mozhet, 2014; O merakh, 2016: 8; Rossiya prokormit, 2016).

We believe that the Belgorod region is economically successful today because of the leadership by governor Yevgeny Savchenko despite his rather paradoxical personal and management views. Thus, on the one hand, he is a staunch statist and supporter of the Kremlin general economic and political lines; on the other hand, he is a welfare state oriented leader and a consistent critic of the post-Soviet market reforms implementation. On the one hand, he skillfully maneuvers between comprehensive support of agroholdings and intensification of large-scale industrial agricultural production; on the other hand, the region aims at strengthening family production and development of organic farming as competitive advantages at the domestic food market. On the one hand, the governor declaratively ensures market economic reforms and supports democratic institutions at the local level; on the other hand, there are few measures to develop civil society, and the governor certainly prefers authoritarian style and patrimonial hierarchical social control.

\section{Leadership features of Yevgeny Savchenko ${ }^{1}$}

Yevgeny Savchenko was born on April 8, $195^{\circ}$ in the village Red Yaruga in the Belgorod region. In 1976, he graduated from the Moscow Agricultural Academy and started his career in agricultural production, first as the chief agronomist of the collective farm Rakityansky, then as the head of the Rakityansky district agricultural department, and then as the director of an elite seed-production state farm. In 1980, he began a political career, first as the first deputy head of the executive committee of the Rakityansky district Council, then as the first secretary of the Shebekinsky City Committee of the Communist Party for the Belgorod region, and then as an instructor for the Central Committee of the CPSU. In 1988, he graduated

1. Basic biographical facts may be found at: http://www.savchenko.ru/info; and http://perebezhchik.ru/person/savchenko-evgeniy-stepanovich.

A.Nikulin,

I.Trotsuk,

S.Wegren

Ideology and

philosophy of the

successful regional development... 
102 from the Rostov Higher Party School and received a doctorate in economics. During 1990-1993 Savchenko was a consultant for the современность Ministry of Agriculture and Food, a general director of the company Russian Seeds, and a deputy chief of the Department of Crop Production in the Ministry of Agriculture and Food. In October 1993, President Boris Yeltsin appointed Savchenko as the head of the regional administration in Belgorod, and then in December 1995 Savchenko was elected governor. In 1996-2001, he also headed the committee for agrarian policy in the Federation Council, and made a reputation as a leading advocate for agrarian interests. In May 1999, he was reelected as governor, and again in May 2003. In June 2007, his authority as a governor was continued by the reappointment by President Vladimir Putin. In October 2012, he was reelected again, and then again in November 2017, thus holding the record for the longest tenure among Russian governors. Under the new law on gubernatorial term adopted in 2012, Savchenko may theoretically continue to govern into 2022.

According to Max Weber's typology of authority (Weber, 1978: 215216), Savchenko is a charismatic leader with strong personality traits who benefits from the traditional Slavophile populism. According to the on-going debates on the relationship of Russian federalism and the powers of regional leaders, Savchenko is an example of the importance of the personality under the strengthening institutional power, i.e. his leader personality at the institutional position with a certain degree of the legislative power played a significant role in regional development despite the fact that since 2000 there has been a purposeful, and largely successful, effort by the federal executive branch to restrain regional elites. There was "a concerted attack on the powers of regions and localities, and a recentralization of economic and political power in the hands of the Kremlin... to bring an end to the 'negotiated federalism' of the Yeltsin era" (Ross, 2009: 20). Several political reforms were introduced to change the power relationship of the federal center with regions (Petrov, Slider, 2016: 6877), to intimidate recalcitrant regional leaders and to enforce loyalty, and the only exception from these restrictive measures was the law that allowed governors to run for a third or even fourth term, which benefited Savchenko. Besides, he also benefited from the institutional design of the gubernatorial powers that has allowed governors to become more powerful compared to other regional actors during 20022012: "in the first half of the 2000s, the consolidation of gubernatorial power enabled most of the regional chief executives to control the legislative agendas of their regions" (Golosov, Konstantinova, 2016: 244).

However, Savchenko is not a governor quietly enjoying his institutional position and avoiding political conflicts that can affect his reputation. He is famous for his careful political behaviour, but he never stayed out of the fights that he considered principal. Thus, 
when in 1999 Vladimir Zhirinovsky announced his candidacy for governor of the Belgorod region, Savchenko and his political team spoke mockingly about Zhirinovsky and called his Liberal Democratic Party "the party of clowns" (Pyrma, 2000). Another example is Savchenko's conflict with the political heavyweight Yuri Luzhkov, or more specifically, with his wife, Yelena Baturina as the head of the Moscow holding company Inteko that was engaged in construction and agribusiness in urban and rural areas of the Belgorod region. At first, the company's projects in the region were growing rapidly, but soon stalled in disputes and scandals with the local communities and authorities primarily over the speculative land purchases, which was one of the first large-scale examples of land-grabbing in rural Russia. Savchenko criticized Inteko for firing too many agricultural workers and not fulfilling its social obligations in rural areas, and Inteko was expelled from the Belgorod region, which once again showed that Savchenko controls his region strictly and effectively. Savchenko's victories in these political fights were determined by his stable relationship with the Kremlin and the United Russia: the governor has always remained loyal to the Putin's rule and consistently ensured $5^{2 \%-54 \%}$ of the vote for the United Russia in elections to the State Duma.

We believe that the economic success of the Belgorod region is due largely to the personality and leadership of Yevgeny Savchenko. Certainly, strong governors exert significant influence over the policies of their regions in ways that go beyond legislation. However, in the Belgorod case this influence is determined not only by the economic policies, which we have already discussed (Nikulin, Trotsuk, Wegren, 2017), but also by ideology and philosophy of the regional leader.

\section{A.V. Chayanov's ideas as roots of the Belgorod Miracle}

The Belgorod governor's project has traditional Russian roots in the spirit of Chayanov's novel "My brother Alexey's journey to the land of peasant utopia", which are: (1) the contradiction between urban and rural ways of life can be resolved based on the village and rural perspective as a priority; (2) a mixed economy can combine both capitalist and state economies provided it is managed in the interests of cooperative and family economies; (3) national culture can survive under the global trends provided the careful and curious study and adaptation of the global cultural experience. In all his utopias, Chayanov developed an original model of social development to find an optimal balance and resolve contradictions between the town and village, industry and agriculture, peasantry and the capitalist state. One of the most underestimated features of the Chayanov's thinking were his original forecasts of future scenarios for both agricultural and social development under various possible political and economic 
104 conditions. His predictions highlight some of the key problems of contemporary Russia. For instance, the state has often underestimated COBPEMEHHOCTЬ the role, potential and needs of small farms and peasant economy preferring large entrepreneurs or 'agroholdings'; there is no social or economic equilibrium in the Russian society, and crises have become an intrinsic part of everyday life; there is a widening gap between political, economic and social decision-makers and population.

Chayanov's novel "My brother Alexey's journey to the land of peasant utopia" presents his most important social-economic and philosophical-aesthetic views (Chayanov, 1989). In this novel, the utopian Moscow and the Moscow region turned into a garden-city, in which cozy and low-rise buildings are interspersed with extensive gardens and parks. The economy of this country is mixed-market, it combines state, cooperative and capitalist economic forms that are carefully monitored and subjected to increased taxation, yet not destroyed as providing incentives for individual entrepreneurship and national economic competition. However, at the core of this system lies individual peasant economy with various forms of cooperation with other economic and cultural modes of life.

Certainly, today Russia is not a self-governing peasant paradise with a mixed economy, rather a bureaucratic authoritarian state with the predominance of large industrial farms. However, Chayanov noted the importance of the deliberate rural-urban cultural policy of the oligarchic leadership in regional development, which has strengthened in the post-Soviet period. The key political prophecy of his utopia is the critical importance of the economic and cultural pressure of the utopian ideology implemented by a team of oligarchs. Today the agrarian oligarchy plays a significant and controversial role in the development of agriculture. On the one hand, oligarchs concentrate substantial resources to implement ambitious rural development projects. On the other hand, these resources are not controlled by the state or rural communities, which leads to corruption scandals and conflicts between agrarian-oligarchic corporations over the redistribution of land and property, and between the capital and the provinces.

In recent decades, the Belgorod modernization project has successfully coped with unpredictable challenges from the Russian oligarchy and global economy, and today it pursues a paradoxical goal - to use the competitive standards of consumer society as the grounds for conservative modernization and solidary society development. The current political and ideological debates focus on the possibility of conservative modernization and its consequences. The Belgorod region is an example of the generally positive systemic effect of the specific type of conservative modernization that has been implemented by Savchenko, who paradoxically combines the roles of a supporter of market economy, a statesman, a conservative and an innovator. 
The Belgorod region shows the fantastic pace of agricultural growth, especially in pig and poultry production, which is the result of the sustainable and dynamic development not only of its agricultural sector, but of social infrastructure in rural areas. In the early $2000 \mathrm{~s}$, the region attracted investments to support large agricultural enterprises. According to Chayanov, these agroholdings represent the "new ways in which capitalism penetrates agriculture. These ways convert the farmer into a labor force working with other people's means of production. They convert agriculture, despite the evident scattered and independent nature of the small commodity producers into an economic system concentrated in a series of the largest undertakings and, through them, entering the sphere controlled by the most advanced forms of finance capitalism" (Chayanov, 1966: 202). In Belgorod agroholdings are carefully monitored and controlled by the regional authorities, which claim that the excessive reliance on huge agroholdings can be dangerous for other economic forms in the countryside. Therefore, Belgorod supports peasant farms and all forms of cooperation at the local level by regional programs of economic, social and cultural development. Certainly, there is poverty in the Belgorod region, but, if we may so, it is more decent than in other rural areas of Russia. Perhaps, the most impressive regional program is "Family Farms of Belogorie". It aims at providing farmers with everything for agricultural production to exclude any side occupations; at making farm products competitive, meeting the high quality standards, and available to consumers; and at developing rural cooperatives and rural social infrastructure.

The regional agrarian reforms proved to be successful due to the combination of the authorities' strict control of land planning and use, development of a mixed agrarian economy, and ensuring a fair price chain between producers, processors and sellers. The Belgorod mixed economy takes advantages of both large and small agricultural production. The rapid growth of powerful agroholdings increases rural unemployment, and special regional programs support family farms in milk production, breeding of small animals and birds (goats, geese), beekeeping, mushroom farms, rural tourism and crafts. The regional authorities implement a wide range of social programs to create 'social agricultural clusters' and prevent the outflow of population from rural areas. As a result, today Belgorod is not only a leader of the agricultural production, but also a territory of the stable demographic growth, educational development, and so on. For instance, in the post-Soviet period the former little-known provincial higher education institutions of the region turned into important national scientific-educational centers. In general, the Belgorod authorities demonstrate a skillful state dirigisme to ensure public support and stimulate local communities' self-organization. The key elements of this dirigisme are housing policy (the region has no equal in Russia in the pace of building private houses with standard

A.Nikulin,

I.Trotsuk, S. Wegren Ideology and philosophy of the successful regional development... 
smallholdings of 0.15 hectares) and a program to support family estates, which aim to overcome the Soviet legacy of the excessive multi-storey, multi-family urbanization, and to revive the traditional neighbor-related lifestyle in the countryside.

The Belgorod governor implements his own model of new economy consisting of the extensive development of solidarity and cooperation, ideals of healthy lifestyle (special environmental programs, the fight against smoking, etc.), and freedom in choosing ways to work and to rest (regional authorities support corporate, family and individual strategies of life). Since 2010, one can see on the billboards of the Belgorod social advertising the call of the Russian religious philosopher Nikolai Fyodorov "To live neither for ourselves or for others, but with all and for the sake of all" as a motto of the new economy leading to the future solidary society. However, today Belgorod rather witnesses a bourgeois neo-NEP although the expansion of capitalist economy is successfully restrained by the regional support of family, cooperative and community economies. To develop the desired solidary society, the authorities promote traditional national values such as orthodoxy, patriotism, and humanistic culture of the old and Soviet Russia, which were impressively described in the Chayanov's utopian novel.

\section{Savchenko's philosophical foundations}

Savchenko is probably the only Russian governor who has publicly articulated his personal political-economic theory. He has repeatedly expressed his ideas in both public statements and published articles over the years. His thinking reflects a conglomerate of conservative, socialist and populist ideas combining anti-liberalism and statist philosophy as the basis for the revival of the Russian state, which he sees as an engine of progress. According to the governor, "the essence of the Belgorod strategy of social and economic modernization is to help our active, cohesive, purposeful, i.e. solidary, society to accelerate the advent of the new type of economy" (Savchenko, 2012: 9).

A central treatise of Savchenko's thinking was an article titled "A task of Stolypin's scale" that appeared on the anniversary of Pyotr Stolypin in the ideological journal of Russian conservatives "Nash Sovremennik" (Our Contemporary) (Savchenko, 2012). Savchenko considers Stolypin's reforms to be more effective and less bloody compared with other famous Russian reformers such as Peter the Great or Joseph Stalin. The Stolypin's reforms are best known for breaking up the communal mir and introducing private ownership of land in the run-up to World War I (Stolypin himself was assassinated in September 1911), though his reforms were much broader and encompassed many other spheres of the economy and social life. In his article, Savchenko identifies several 
policy directions and reforms for Russia that he argues Stolypin would certainly have implemented if he were still alive. We review the main points in his thinking and then show linkages to actual policy in the Belgorod region.

The Savchenko's ideas reflect strong elements of statism that shape his worldview. His philosophical foundation is summarized by the following quote: "State power always has to solve a lot of current and strategic tasks, however, statesmen at all levels must never forget about the mission of the state - to reveal the spiritual, moral, intellectual, creative potential of the people, which constantly requires fresh, thought-out, uniting ideas and, most importantly, effective actions to implement them. The soul of the Russian people yearned for a great common task on a Stolypin scale!" (Savchenko, 2012: 11). While Savchenko is undoubtedly a statist, he is also pragmatic and has worked to encourage small enterprises and the private economic sector in agricultural and non-agricultural spheres.

In the article, Savchenko argues for social justice and reducing inequality. He maintains that in contemporary Russia the majority of national income is expropriated by the owners of capital in the form of business income, dividends, foreign accounts, and corruption schemes. Only one-third of national income goes to the state through taxes, fees and fines. He is opposed to the unequal distribution of income and existing disparities in wealth.

Savchenko claims that the mileage of Russian railways has remained virtually unchanged since the Stolypin reforms. The highway system that was initially designed for the width of two horse drawn carts has basically stayed the same. As a result, Russia loses several trillion rubles a year due to its lack of roads; and bad quality roads are the cause of up to 40 thousand deaths and hundreds of thousands of injuries per year.

Savchenko argues that regional demographic problems and outmigration may be addressed through housing reform, reform of the communal service sector, and improvement in the educational system. Savchenko believes in a strong state-led education system and criticizes the today's system that "creates the rules in its own interests". The commercialization of education practically excludes the state and the employer. The vocational training system has been simplified to the level of primitivism whereby education is little more than an exchange: the institution is interested in receiving money, and the student is interested in getting a diploma. As a result, graduates receive poor quality training and are not well-prepared with skills required by the labor market.

Savchenko considers Russian health care to be ineffective, costly, cumbersome, and corrupt despite recent significant improvement in funding. Savchenko criticizes the health care system for failure to provide high-quality services; and patients for their unwillingness to live a healthy lifestyle.
107

A.Nikulin,

I.Trotsuk,

S. Wegren

Ideology and

philosophy of the

successful regional development... 
Finally, Savchenko is an advocate for the development of an innovative economy: he favors shifting responsibility for funding research from the state to corporations as is the practice in many developed nations.

Savchenko favors the active participation of the state, which he believes will inevitably lead Russia to a spiritual-moral revolution. He argues that "the moral degradation of society in recent years has gone so far that it threatens the very existence of the state" (Savchenko, 2012: 11). The driving forces of this new revolution are state power, traditional religion, and the intelligentsia. Savchenko developed a road map for the moral recovery of the society, consisting of: (1) an enhanced role of traditional religion, primarily of the Russian Orthodox Church; (2) strengthening the idea of the paramount importance of the Russian ethos as a foundation of the state; (3) control over mass media and the Internet; (4) development and support for all public forms of local self-government; (5) state funding of schools at the level so that teacher's salary would be twice the average in the economy, thus contributing to the prestige of the school teacher profession; (6) strengthening the family as an institution and a ban on abortion except for medical reasons; (7) tougher administrative penalties for violation of ethical norms (intolerance, bad language, etc.).

Below we link the ideas articulated in "A task of Stolypin's scale" to policies Savchenko has advocated for the nation or implemented in the Belgorod region. The ideas are important because they show a wide-ranging concern for development of the region in many different spheres. Although Savchenko is a strong advocate for agrarian interests, his leadership concerns extend beyond the agricultural sector. Savchenko's ideas are simultaneously far-reaching and yet sometimes his statism resembles policy outcomes that one would expect in a planned economy of the interventionist and regulatory state.

Social justice: Savchenko insists on state intervention in the redistribution of national income through legislation. Wage workers receive about $20 \%$ of revenues, which Savchenko considers absolutely unfair. He suggests redistribution of income between the ownersemployers and employees in favor of the latter because "labor as an economic category stands above capital" (Savchenko, 2012: 5). Further, he has called for transferring one-third of property assets of commercial enterprises, regardless of its ownership, to labor collectives. As a result, the share of the workers in the enterprise's income would increase through wages and dividends; economic and financial activities of the enterprises would become transparent; and the distribution of one-third of the capital among employees would lead to the capitalization of labor collective. Thus, there would appear new incentives for improving labor discipline, building careers, developing professional skills, and promoting efficiency and competitiveness of the enterprise. According to Savchenko, "such historic decisions 
reveal a new conflict-free perspective of social-political development" (Savchenko, 2012: 6).

Rural infrastructure and roads: Savchenko calls for the connection of all regional and district centres of Russia with modern, high-speed, four-lane highways by building and reconstructing 100 thousand kilometers of roads. This task requires a huge sum of money (about $\$ 240$ billion), which Savchenko has suggested to raise through a special tax policy. Savchenko's commitment to roads and infrastructure is seen by the fact that Belgorod ranked 1st in the Central Federal district in 2015 in kilometers of hard paved roads on a standardized basis of per 1,000 square kilometers of territory (excluding Moscow).

Demography and migration: Savchenko proposes to address demographic problems through assistance for housing and the acquisition of land. He has suggested that all citizens who want to live in their own houses may receive a state loan for up to 25 years and acquire a plot of land up to one hectare with infrastructure, including roads. According to Savchenko, loan terms as well as the size and conditions for receiving a plot of land should differ depending on the region. In Siberia and the Far East with low population density and a high migratory outflow, loan terms should be favorable and the land plot should be granted free of charge. In the Moscow metropolitan area and fertile southern regions with a high population density, no credit should be provided and land should not be distributed free of charge to stimulate outflow of population to other regions where land is free. Throughout Russia, the construction of individual houses should number no fewer than 500 thousand houses per year; the source of financing would come from loans by the Central Bank of Russia and cost about $\$ 24$ billion dollars a year. If Russia were to undertake such a program, Savchenko believes that, "in the next twenty years about $5^{\circ}$ million Russians would have moved to their own houses; depopulation in the Slavic ethnic group would have stopped, and the physical and moral state of the society would have strengthened. Together with the road construction, these changes will lead to tremendous economic growth, the spiritual unity of the nation, the emancipation of the creative potential of the people, i.e. to solving the main task of modernization... This is where we have to invest oil revenues today to turn our perishable wealth into imperishable national wealth" (Savchenko, 2012: 7).

The Belgorod region is demographically unique among regions in the Central Federal district in two ways. First, in contrast to other regions, Belgorod's population has been increasing since 1991. All regions in the Central Federal district have experienced a decline in population during 1991-2016 due to both outmigration and a negative natural increase. The only exceptions are the Moscow region, which is truly an outlier not only in the Central Federal district but also for all of Russia in terms of investment, economic activity, income levels, 


\begin{tabular}{lllll}
\hline Year & $\begin{array}{l}\text { Total } \\
\text { population, } \\
\text { in millions }\end{array}$ & $\begin{array}{l}\text { Net population } \\
\text { change from } \\
\text { previous year }\end{array}$ & Net migration & $\begin{array}{l}\text { \% of } \\
\text { population } \\
\text { of pension age }\end{array}$ \\
\hline 1991 & 1.399 & $+8,000$ & $+9,506$ & 22.9 \\
1996 & 1.467 & $+11,000$ & $+18,233$ & 23.3 \\
2000 & 1.495 & $+5,000$ & $+14,901$ & 23.4 \\
2005 & 1.512 & no change & $+10,133$ & 22.8 \\
2010 & 1.532 & $+6,000$ & $+5,975$ & 24.1 \\
2011 & 1.536 & $+4,000$ & $+8,350$ & 24.5 \\
2012 & 1.541 & $+5,000$ & $+4,059$ & 25.0 \\
2013 & 1.544 & $+3,000$ & $+6,566$ & 25.5 \\
2014 & 1.548 & $+4,000$ & $+7,591$ & 26.1 \\
2015 & 1.550 & $+2,000$ & $+5,918$ & 26.6 \\
\hline
\end{tabular}

Sources: Goskomstat RSFSR, 1991: 78; Goskomstat Rossii, 2001: 21; Goskomstat Rossii, 1997: 25, 512, 518; Rosstat, 2015: 37, 45; Rosstat, 2016: 49; Chislennost i migratsiya naseleniya Rossiiskoi Federatsii (Moscow: Rosstat), various years; and authors' calculations.

and opportunity; and the Belgorod region. The second way the region is unique is that it experiences net in-migration: the natural increase is negative - the death rate exceeds the birth rate, but positive net migration compensates and the population continues to grow, albeit slowly. This trend is shown in Table 1.

Education: Savchenko proposes free education and to transfer the expenses to the state budget and employers (50/50 split). According to his plan, an employer could pay its share in a year after checking the graduate's qualification and skills at work based on the joint evaluation by a special commission comprised of representatives of the educational institution, employer, and the state. Therefore, the graduate would get a diploma only after a year of work. Savchenko also argues that regional and federal authorities should require all educational institutions, state and private, to create a long-term plan for training specialists (seven to ten years). This plan should be based on employers' requests and forecasts of national economic and social development, which would make educational institutions responsible for the quality of training. State educational institutions would have to produce a required number and quality of specialists, a situation would guarantee employment to all graduates and could lead to closing unneeded or low quality educational institutions.

Health care: Savchenko proposes to change the model of financing health services by introducing a personal account for every citizen, to be replenished annually by about $\$ 25^{\circ}$ dollars (the amount would depend on the age of the recipient). If the cost of medical services 
exceeds personal funds, relatives and friends would be responsible for adding money from their personal accounts or funds. A person would be able to spent money from his personal account only on health care purposes; however, at the end of the year unused funds could be used to pay for activities related to health improvement (e.g., fitness, sports), or to carryover for medical services in the next year. According to Savchenko, this reform would stimulate real competition among medical institutions, although the number of providers would decrease. Moreover, health care personnel would get decent salaries for good work. At the same time, a person would be motivated to monitor one's health, and the family would strengthen control over the lifestyle of its members to prevent unhealthy lifestyles (smoking, drinking), which would result in strengthening the family institution in general.

Innovation in the economy: Savchenko has introduced policies that favor the development of small enterprises. In 2014, excluding the city of Moscow, Belgorod ranked 1st in the Central Federal district in number of small enterprises (agricultural and nonagricultural). Nationwide, excluding the cities of Moscow and Saint Petersburg, Belgorod ranked 22nd in number of small enterprises. On a standardized scale, Belgorod ranked $17^{\text {th }}$ in number of small enterprises per 1,000 people (excluding Moscow and Saint Petersburg). Belgorod also ranked 26th in trade turnover by small enterprises (Rosstat, 2015: 556-557). Savchenko proposes legislation to obligate enterprises to allocate at least $5 \%$ of their net profit to innovative research programs, either their own or in cooperation with scientific institutions and universities. Savchenko believes that this measure would increase the annual funding of corporate research and development up to $\$ 8$ billion, which is several times higher than the current level of state funding. If implemented, this policy would lead to an increase in demand for talent, in competitiveness and capitalization of business, in demand for innovative domestic products, and in competition between educational institutions for innovative corporate orders. Further, Belgorod is a leader in other innovative indicators. For instance, regional authorities established a Council on Innovative Policies and adopted a long-term program called "The Development of Nanotechnology Industry in Belgorod region." This program opened a business incubator, started the construction of the "North" industrial park, created innovative regional economic clusters in agrofood, mining-metallurgy and construction, and cooperated with the largest private companies in funding and research work.

Going forward, the importance of Belgorod is likely to increase due to the importance that the government is placing on organic agriculture. Toward this end, a law on organic agriculture was adopted in early 2018, and cooperation with Germany to develop organics was announced in late 2017 . Belgorod is likely to emerge as a leading organic producer as Russia strives to become a major 
112 international player in organic food. Second, the new version of the food security doctrine approved by the Ministry of Agriculture in современность February 2018 places emphasis on food exports that will benefit the economy in Belgorod.

\section{Conclusion}

Today in Russia, the gubernatorial power is enhanced by both institutional design of the authority distribution and the personal leadership. As the Belgorod case shows, a governor can remain very powerful within his region, even beyond the political power granted by his institutional position. Thus, there are many governors in Russia with the same or even better requisites that cannot compete with the Belgorod region's economic and social achievements. The 'Belgorod Miracle' is attributable to Savchenko's policies favoring a mixed economy and state-guided capitalism, whereby the state guides private actors and the market through support for specific industries and businesses, expansion of employment, modernization of services, and support for welfare of the population.

Certainly, the situation is not ideal, and the Belgorod region faces many challenges as the rest of Russia, but the Belgorod authorities often manage to cope with difficulties effectively and socially responsible. For instance, during his first term as a governor (19992003) Savchenko began to introduce agrarian reforms that attracted significant investments in agriculture and supported emerging agroholdings. Belgorod was among the first regions to create large agroholdings, which have become the engines of agricultural growth in the region and nationally (Uzun, 2008). As the number of agroholdings rapidly grew, the "red landlords" of the 199os were attacked by the "white oligarchs" of the 2000s. Financial and other companies rushed into agriculture, engaged in land grabbing, and became large capitalist corporations resembling uncontrolled giant latifundia that support the corrupt state bureaucracy and exploit powerless agricultural workers. By 2009 , about two-thirds of all agricultural enterprises in the Belgorod region belonged to agroholdings that produced 9o\% of the region's total agricultural output, farmed two-thirds of its land, and employed $72 \%$ of the agricultural workforce (Epshtein, Hahlbrock, Wandel, 2013). Further, agroholdings use generous regional subsidies to become substantial food producers, and the region is home to some of the largest and financially strongest agroholdings in the country: Miratorg, Efko, Prom-Agro, and Agro-Belogorye. There are often close ties between the governor's office and agroholdings (not only in the Belgorod region). For instance, Savchenko helped Genandiy Bobritskiy to establish the poultry holding company Prioskolye, and Vladimir Zotov to establish Agro-Belogorye, and provided support to make them successful (Volkov, 2016). Moreover, the regional 
government, as in some other regions, has imposed restrictions on livestock meat production by smallholders, which the agroholdings have actively lobbied for to wipe out the competition of cheap meat from the smallholders under the banner of sanitary measures (e.g.: Visser et al, 2015).

The Krasnodar region became the center of land grabbing in Russia over the last two decades due to the domination of agroholdings actively pushing smallholders from financially attractive spheres of agriculture, and affiliating with local political elites. The Belgorod authorities force and persuade (albeit not always successfully) huge agroholdings to meet expectations of the regional government and local communities regarding social obligations. It means that agroholdings at least imitate corporate social activities and position themselves as socially responsible businesses. The regional authorities also support family farms against the aggressive accumulation by agroholdings, while in other regions the authorities prefer to collaborate with agroholdings, which negatively affects smallholders and family farmers. Thus, in addition to various agricultural programs, Savchenko's policies support agrarian development in three basic directions: (1) a mixed economy, consisting of agroholdings, cooperatives and family farms; (2) rural social clusters that develop both agricultural production and rural social infrastructure; (3) a symbiotic relationship between agriculture and sustainability.

As a result, in the Belgorod region, agroholdings dominate in terms of output, value of production, financing, and cultivated land, while the number of private farms has declined, but the number of registered household gardens has increased though not substantially. Many rural regions in the Central Federal district, and throughout Russia, have experienced significant depopulation due to outmigration during the past 40-50 years, while the Belgorod region's population has increased since 1991 and remain a net recipient of migrants. Savchenko recognizes the inherent link between rural social conditions, agricultural production and demographic trends (Savchenko, 2009: 9). Therefore, he has implemented a wide range of social programs to create 'social agricultural clusters', which make the region a territory with social stability in rural areas.

Thus, the Belgorod development model implies a wide range of local resources and diversification of economic activities; the regional authorities revive the 'collectivist' model of rural life by combining federal support of the agrarian sector (primarily agroholdings) with regional and local initiatives aimed at harmonizing interests of different economic and social actors (by assigning agroholdings some social and ecological obligations, by attracting large and medium-scale business to the 'paternalistic' participation in social projects in the countryside). Such a variety of regional authorities' priorities corresponds to the Chayanov's notion of diversity given the social-economic, historical and cultural conditions of rural-urban
113

A.Nikulin,

I.Trotsuk,

S.Wegren

Ideology and

philosophy of the

successful regional development... 
114 lifestyles reciprocity. It also leaves no doubts that the governor's anti-crisis program (Savchenko, 2015), presenting an ambitious plan СOBPEMEHность for achieving further economic growth despite a macro-environment of resource constraints, is realistic given the governor's active and assertive leadership style based on a combination of statism and market capitalism.

\section{References}

Chayanov A.V. (1966) The Theory of Peasant Economy. Ed. by D. Thorner, B. Kerblay,

R.E.F. Smith. Homewood, Illinois: Richard Irwin for the American Economic Association.

Chayanov A.V. (1989) Puteshestvie moego brata Alekseja v stranu krestjanskoj utopii [My brother Alexey's journey to the land of peasant utopia]. Venetsianskoe zerkalo: Povesti. Moscow: Sovremennik.

Dyatlovskaya E. (2016) Tkachev: Rossiya obespechit sebya produktami cherez sem let [Tkachev: Russia will supply itself with food products in seven years]. https://www.agroinvestor.ru/analytics/ news/2526o-tkachev-rossiya-obespechit-sebya-produktami-cherez-sem-let.

Epshtein D., Hahlbrock K., Wandel J. (2013) Why are agroholdings so pervasive in Russia's Belgorod Oblast? Evidence from case studies and farm-level data. Post-Communist Economies. No. 25.

Evgeniy Savchenko: Rossiya mozhet prokormit 500 millionov chelovek [Evgeny Savchenko: Russia can feed 500 million people] (2014). https://www.semlot.ru/suverenitet/1184-evgenij-savchenko-rossiya-mozhet-prokormit-500-millionov-chelovek.

Fadeeva O.P. (2013). Socioeconomic potential of multipattern rural economic systems (the case study of Belgorod Oblast). Regional Research of Russia. No. 3.

Golosov G., Konstantinova M. (2016) Gubernatorial powers in Russia: The transformation of regional institutions under the centralizing control of the federal authorities. Problems of Post-Communism. No. 63.

Goskomstat Rossii (1997) Demograficheskiy ezhegodnik Rossii [Demographic Yearbook of Russia]. Moscow: Goskomstat.

Goskomstat RSFSR (1991) Narodnoye khozyaystvo RSFSR v 1990 g. [National Economy of the RSFSR in 1990]. Moscow: Goskomstat RSFSR.

loffe G., Nefedova T. (2000) Areas of crisis in Russian agriculture: A geographic perspective. Post-Soviet Geography and Economics. No. 41.

Kulistikova T. (2017) Na top-10 regionov prishlos 40\% proizvodstva selkhozproduktsii v strane [Top 10 regions accounted for $40 \%$ of the agricultural production in the country]. https://www.agroinvestor.ru/analytics/ news/26303-na-top-10-regionov-prishlos-40-proizvodstva.

Nikulin A.M., Trotsuk I., Wegren S.K. (2017) The importance of strong regional leadership in Russia: The Belgorod Miracle in agriculture. Eurasian Geography and Economics. Vol. 58. No. 3 .

O merakh po uskorennomu razvitiyu podotrasley selskogo khozyaystva [On measures to accelerate development of sub-branches of agriculture] (2016). Selskaya Zhizn. July 7-13.

Petrov N., Slider D. (2016) Regional politics. Putin's Russia: Past Imperfect, Future Uncertain. Ed. by S.K. Wegren. Lanham: Rowman and Littlefield.

Pyrma R. (2000) Agrariy (Nabrosok politicheskogo portreta Yevgeniya Savchenko) [An agrarian (A sketch of Yevgeny Savchenko's political portrait)]. Pro et Contra. No. 5 .

Reiting effektivnosti gubernatorov [Ranking of gubernatorial effectiveness] (2016). https:// civilfund.ru/mat/101. 
Ross C. (2009) Local Politics and Democratization in Russia. London: Routledge.

Rossiya prokormit polmilliarda chelovek, pomogut kolkhozy - mnenie [Russia can feed half a billion people, with the help of collective farms] (2016). https://social.pravda.ru/ blog/43437883754/Rossiya-prokormit-polmilliarda-chelovek,-pomogut-kolhozyimnen?page $=2 \# 42074990347$.

Rosstat (2015) Regiony Rossii: sotsialno-ekonomicheskiye pokazateli [Regions of Russia: Socioeconomic Indicators]. Moscow: Rosstat.

Rosstat (2016) Regiony Rossii: sotsialno-ekonomicheskiye pokazateli [Regions of Russia: Socioeconomic Indicators]. Moscow: Rosstat.

Savchenkko E. (2015) Antikrizisnaya programma Belgorodskoy oblasti [The anticrisis program of Belgorod region]. APK: ekonomika, upravleniye. No. 5 .

Savchenko E. (2009) Strategiya razvitiya agrarnogo sektora i selskikh territoriy Belgorodskoy oblasti [The strategy for development of the agrarian sector and rural territories of Belgorod region]. APK: ekonomika, upravleniye. No. 12.

Savchenko E.S. (2012) Delo Stolypinskogo masshtaba [A task of Stolypin's scale]. Nash Sovremennik. No. 4.

Uzun V. (2008) Large and small business in Russian agriculture. Russia's Agriculture in Transition: Market Factors and Constraints on Growth. Ed. by Z. Lerman. Lanham: Lexington Books.

Visser O., Mamonova N., Spoor M., Nikulin A. (2015) "Quiet food sovereignty” as food sovereignty without a movement? Insights from post-socialist Russia. Globalizations.Vol. 12. No. 4.

Volkov A. (2016) Trevozhnyy znak dlya "politicheskogo tyazhelovesa" [A disturbing sign for a "political heavyweight"]. https://versia.ru/korrupcionnye-skandaly-poshatnuli-rejting-gubernatora-belgorodskoj-oblasti-evgeniya-savchenko.

Weber M. (1978) Economy and Society. Vol. 1. Ed. by G. Roth, C. Wittich. Berkeley: University of California Press.

Wegren S.K., Nilssen F., Elvestad C. (2016) The impact of Russian food security policy on the performance of the food system. Eurasian Geography and Economics. No. 57.

\section{Идеология и философия успешного регионального развития В современной России: белгородский кейс}

Александр Михайлович Никулин, кандидат экономических наук, директор Центра аграрных исследований Российской академии народного хозяйства и государственной службы при Президенте Российской Федерации. 119571, Москва, просп. Вернадского, 82. E-mail: harmina@yandex.ru.

Ирина Владимировна Троцук, доктор социологических наук, ведущий научный сотрудник Центра аграрных исследований Российской академии народного хозяйства и государственной службы при Президенте Российской Федерации; доцент кафедры социологии Российского университета дружбы народов. 119571, Москва, просп. Вернадсклго, 82. E-mail: irina.trotsuk@yandex.ru.

Стивен Вегрен, профессор политологии, Южный методистский университет Далласа (Texac, США). E-mail: swegren@smu.edu.

Экономические успехи Белгородской области представлены в статье как в значительной степени результат аграрных реформ губернатора Евгения Степановича Савченко, которые компенсируют небольшой размер региона и его скромный человеческий капитал. В 2017 году авторы опубликовали статью, в которой подробно описаны экономические и социальные программы регионального правительства, сейчас акцент сделан на лидерском стиле 
116 губернатора и его весьма парадоксальных личных и управленческих взглядах. Вопервых, согласно типологии Макса Вебера, Е.С. Савченко - харизматический лидер с сильным характером и осторожный политик, который успешно использует традиционные идеи славянофильства и нынешний институциональный формат губернаторской власти, предоставляющий губернаторам больше полномочий, чем в 2002-2012 годы. Во-вторых, проекты белгородского губернатора вполне соответствуют духу известной работы А.В. Чаянова "Путешествие моего брата Алексея в страну крестьянской утопии", что позволило области успешно противостоять давлению российских олигархов и глобальной экономики, используя стандарты конкуренции общества потребления как фундамент для консервативной модернизации и солидарного общества. Белгородский губернатор последовательно реализует собственную экономическую модель, сочетающую широкое развитие солидарности и кооперации, идеалы здорового образа жизни и гарантии свободы в выборе способов занятости и отдыха. В-третьих, губернатор публично озвучивает свои политэкономические взгляды, представляющие конгломерат консервативных, социалистических и народнических идей и сочетающие антилиберализм и государственничество как основу возрождения российского государства в качестве двигателя общественного прогресса.

Ключевые слова: Белгородская область; губернатор; лидерство; региональные власти; региональное развитие; идеологические истоки; философские основания. 